The organization of the exhibition MADE IN U.S.A. and the publication of this book have involved the assistance, advice, and cooperation of many people. Private collectors were extremely generous in sharing their art and providing enriching information. I am decply grateful to those who have lent works to the exhibition. Artists were also most helpful in discussing their work or the period, or in assisting with loans. I am especially indebted to Robert Ameson, Rudolf Baranik, Robert Bechtle. Tony Berlant, Jake Berthot, Bruce Conner, Allan D'Arcangelo, Wally Hedrick, George Herms, Jess, Jasper Johns, Ray Johnson, Allan Kaprow, Edward Kicnholz, Alfred Leslie, Gladys Nilsson, Jim Nutt, Claes Oldenburg, Robert Rauschenberg, Edward Ruscha, Peter Saul, George Segal, May Stevens, Wayne Thiebaud, Robert Watts, and Tom Wesselmann.

My research was enhanced by conversations with individuals who participated in the American art world of the r950s and ig6os, and with scholars who specialize in the postwar era. For this I extend thanks to Richard Abrams, Demis Adrian, Don Baum, Richard Bellamy, Irving Blum, Peter Boswell, Ernest A. Busche, Mary Schmidt Campbell, Leo Castelli, John Coplans, Wanda Corn, Robert Dcan, Todd Gitlin, Harold Glicksman, Barbara Haskell, Ruth Horwich, Richard Hutson, Thomas A. Leonard, Lawrence Levine, Kathleen Moran, Michacl Rogin, Peter Sclz, John Weber, and William S. Wilson.

For their time and kindness in facilitating loans and providing documentation, l owe a large measure of gratitude to the following: Thomas A mmann Finc Art (Monica Burri), Betty Asher, Leo Castelli Gallery (Lisa Martizia), Sarah H. Cooke, Terry Dintinfass, Virginia Dwan, Allan Frumkin, Joni Gordon, Nora Halpern, Wanda Hansen, Joseph A. Helman, Nick Howey, Sidncy Janis Gallery, Phyllis Kind Gallery (William H. Bengtson), Margo Leavin, Louis K. Meisel Gallery, Olivia Motch, Reinhard Onnasch, Richard L. Palmer, Cora Rosevear, William S. Rubin, SalanderO'Reilly Galleries, Sonnabend Gallery (Antonio Homem), Frederick Voss, and David White.

During the coursc of planning this project, I have enjoyed the support and assistance of the entire staff of the University Art Museum. I particularly wish to thank James Elliott, director; Ronald Egherman, deputy director; Mary Ellen Murphy, development director; Edith Kramer, curator of film; Nina Hubbs, head of installation and design; Arnold Sandrock, business manager; Barbara Berman, publicist; and Jane Kamplain, registrar. For their attention to the myriad of details associated 
with preparing the texts and securing loans and photographs, I am extremely grateful to Joan Perlman, Eve Vanderstoel, and Marijke van Doorn. I have also had the good fortune of having a superb assistant, Elizabeth Boone, who has worked with diligence, efficiency, and good humor on all aspects of this project.

Colleagues at the museums on the tour of the exhibition have been most helpful and delightful to work with. My sincere thanks to Marc F. Wilson and Deborah Emont Scott at The Nelson-Atkins Museum of Art, and Paul N. Perrot, Richard B. Woodward, and Frederick R. Brandt at the Virginia Museum of Fine Arts.

For her sustained interest in this project, Mary Jane Hickey of the Henry Luce Foundation deserves special mention.

The publication of this book is the result of the care and expertise of the University of California Press. I particularly thank Amy Einsohn for her insightful, sensitive editing, Steve Renick for his outstanding design, Marilyn Schwartz for her skillful supervision of the production, and Laird Easton for his general assistance. To Jim Clark, whose unfailing confidence in this project and personal encouragement have been a source of strength throughout, I am profoundly grateful.

Lastly, I thank Ben H. Bagdikian, James Breslin, and Thomas Schaub, whose essays add significantly to the content of this book, and Moira Roth for her constructive reading of the text, her continued enthusiasm for the project, and her warm friendship.

\section{PHOTOGRAPH CREDITS}

Thomas Ammann Fine Art, Zurich: I 5 I. Jörg P. Anders, Berlin: I12. Art Gallery of Ontario, Toronto: 75. William H. Bengston, Chicago: 143 , I 80. Ben Blackwell, Berkeley: 6, 10, 56, 66, 72, 144, I49. Jon Blumb, Lawrence, Kansas: 179. Rudolph Burckhardt, New York: 103, I24. Rudolph Burckhardt, courtesy Leo Castelli Gallery, New York: 1 58, 190. Leo Castelli Gallery, New York: 36. Geoffrey Clements, New York: 76, 107, 145 , 192. Charles Cowles Gallery, New York: 104, I so. Bevan Davis, courtesy Leo Castelli Gallery, New York: 152, I 53. D. James Dee, courtesy David McKec Gallery, New York: 14. The Detroit Institute of Arts: I 8I. W. Drayer, Zurich: 89. ecva-inkeri, New York: 41 . Thomas Feist, New York: 33. Chuck Garner, Vermillion Photographic, Phoenix: 8o. Hickey and Robertson, Houston: 22. Sidney Janis Gallery, New York: I 32. Jochen Littkemann, Berlin: 35. Alfred Lutjeans, Los Angeles: I 54. Robert R. McElroy, New York: Io I. Joseph Maloney, New York: 91. Robert E. Mates, New York: 88, I77. Louis K. Meisel Gallery, New York: 49. Robert Miller, Portland, Oregon: 170. The Museum of Modern Art, New York: 18, 127. Otto E. Nelson, Ithaca, New York: 17I. William Nettles, Los Angeles: 95. Douglas M. Parker, Los Angeles: 32, 55, 67, 169, 173. Eric Pollitzer, New York: 8, 16, 17, 43, 81, 98, 129, 131, 178, 191. Eric Pollitzer, courtesy Leo Castelli Gallery, New York: 23. Nathan Rabin, New York: 13, 118 . Nathan Rabin, courtesy Allan Frumkin Gallery, New York: 92. Rheinisches Bildarchiv, Cologne: 100, 139, 195. Terry Richardson, Charleston, South Carolina: 57. Walter Rosenblum, South Hadley, Massachusetts: I 84. Friedrich Rosensticl, Cologne: 194. Paul Ruscha, Los Angeles: 50. Salander-O'Reilly Galleries, Inc., New York: 113. Sandak, Inc., New York: 188. Manu Sassoonian, New York: 42. Schenck and Schenck, New York: 68. Marc Schuman, Glenwood Springs. Colorado: I 20. Harry Shunk, courtesy Leo Castelli Gallery, New York: 7. ShunkKender, New York: 196. Squidds \& Nunns, Los Angeles: 26, 29. 77, I I6, 117 , 166. Statens Kunstmuseer, Stockholm: I I I, 193. Jerry L. Thompson, Amenia, New York: 78, I 46. Roland I. Unruh, Miami: 94. Tom Van Eynde, Chicago: 47, 93, I 26, 135. Malcolm Varon, New York: I 82, 183. Tom Vinetz, New York: 165. Wadsworth Atheneum, Hartford, Connecticut: 102. Robert Watts, Bangor, Pennsylvania: 79. David Webber, Boston: I5, I 89. Ellen Page Wilson, Phoenix: 121. Dorothy Zeidman, New York: 9, I I, I 2. 
LENDERS TO

\section{MADE IN U.S.A. EXHIBITION}

Robert E. Abrams

Akron Art Museum, Akron, Ohio

Allen Memorial Art Museum, Oberlin College, Oberlin, Ohio

The Stephen S. Alpert Family Trust

Art Gallery of Ontario, Toronto

Lawrence and Evelyn Aronson

The Art Institute of Chicago

Ruth Askey

Rudolf Baranik

Robert H. Bergman

Jake Berthot

John Bransten

The Edward R. Broida Trust, Los Angeles

Carolina Art Association, Gibbes Art Gallery,

Charleston, South Carolina

Richard V. Clarke

Harold Cook

William N. Copley

Charles Cowles Gallery, New York

Susan Dakin

Allan D'Arcangelo

Roger I. Davidson

The Detroit Institute of Arts

Norman Dolph

Robert Duncan

Mr. and Mrs. Alan Englander

Betty and Monte Factor

Fort Worth Art Muscum, Fort Worth, Texas

Allan Frumkin Gallery, New York

Diana Fuller

Mr. and Mrs. Raymond Goctz

Foster Goldstrom

The Grinstein Family

Hood Museum of Art, Dartmouth College,

Hanover, New Hampshire

Walter Hopps

Mrs. Ruth Horwich

Marian B. Javits

Jasper Johns

Herbert F. Johnson Museum of Art, Cornell

University, Ithaca, New York

Ray Johnson

Margo Leavin Gallery, Los Angeles

Sydney and Frances Lewis

Lewis \& Clark College, Portland, Oregon

David Lichtenstein

Mead Corporation Collection, Dayton, Ohio

Miami University Art Museum, Oxford, Ohio

The Museum of Modern Art, New York

Walter and Anne Nathan
National Gallery of Art, Washington, D.C.

National Museum of American Art, Smithsonian Institution, Washington, D.C.

National Portrait Gallery, Smithsonian Institution, Washington, D.C.

The Nelson-Atkins Museum of Art, Kansas City, Missouri

Neuberger Museum, State University of New York at Purchase

Newport Harbor Art Museum, Newport Beach, California

Claude Nutt

Jim Nutt

Odyssia Gallery, New York

Clacs Oldenburg

Joan and Jack Quinn

Scot Ramos

Robert Rauschenberg

Faith Ringgold

Larry Rivers

Jane and Ruth Root

Mary Lou Rosenquist

Edward Ruscha

Santa Barbara Museum of Art, Santa Barbara, California

The Schomburg Center for Research in Black Culture, New York Public Library

Robert Shapazian

Sinith College Museum of Art, Northampton, Massachusetts

Ileana and Michael Sonnabend

Sonnabend Gallery, New York

Stanford University Museum of Art, Stanford, California

Allan Stone Gallery, New York

Marc and Livia Straus

Wayne Thiebaud

Mr. and Mrs. Burton Tremaine

University Art Museum, University of California, Berkeley

Virginia Museum of Fine Arts, Richmond

Wadsworth Atheneum, Hartford, Connecticut

Sam Wagstaff

Walker Art Center, Minneapolis, Minnesota

Washington University Gallery of Art, St. Louis, Missouri

The Frederick R. Weisman Foundation of Art, Los Angeles

Marcia S. Weisman

Whitney Museum of American Art, New York

William S. Wilson

Laura-Lee W. Woods

Anonymous lenders 
